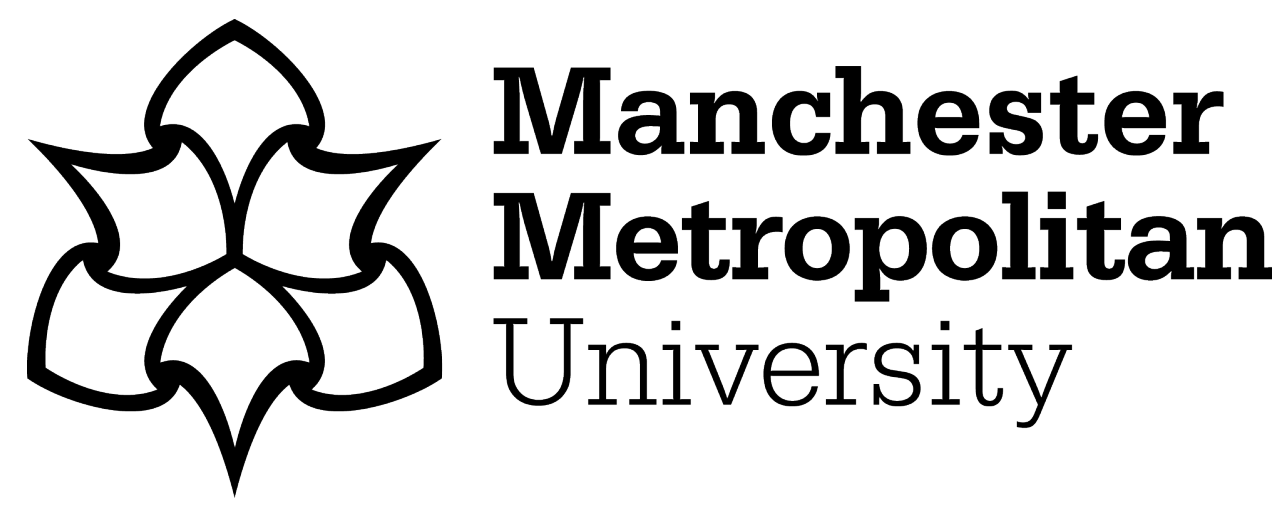

Pais, A and Costa, M (2020) An ideology critique of global citizenship education. Critical Studies in Education, 61 (1). pp. 1-16. ISSN 1750-8487

Downloaded from: https://e-space.mmu.ac.uk/619722/

Version: Accepted Version

Publisher: Taylor \& Francis (Routledge)

DOI: https://doi.org/10.1080/17508487.2017.1318772

Please cite the published version 


\section{An ideology critique of global citizenship education}

In the last two decades, global citizenship education has become a catchphrase used by international and national educational agencies, as well as researchers, to delineate the increasing internationalisation of education, framed as an answer to the growing globalisation and the high values of citizenship. These developments, however, have created issues, due to the presence of two conflicting discourses. While the discourse of critical democracy highlights the importance of ethical values, social responsibility and active citizenry, a neoliberal discourse privileges instead a market-rationale, focused on self-investment and enhanced profits. These two discourses are not separated; they rather appear side by side, causing a confusing effect. This article aims to analyse global citizenship education as an ideology, unveiling not only its hidden (discursive) content, but also the role played by nondiscursive elements in guaranteeing the co-existence of antagonistic discourses. It will be argued that not only the critical democratic discourse does not offer any resistance or threat to the neoliberal structuring of higher education, this discourse can function as an apologetic narrative that exculpates all of us who still want to work in universities, notwithstanding our dissatisfaction with their current commodification.

Keywords: global citizenship education, neoliberalism, critical democracy, ideology, enjoyment, Lacan, Žižek

\section{Introduction}

The United Nations Educational Scientific and Cultural Organisation (UNESCO) recently posited global citizenship education $(\mathrm{GCE})^{1}$ as one of the strategic areas of work of the United Education Programme (2014-2017), and one of the three priorities of the United Nations Secretary-General's 'Global Education First Initiative' launched in September $2012^{2}$. In the document 'Global Citizenship Education: An Emerging Perspective' (2013), UNESCO provides the rationale for the implementation of global citizenship education across different countries. This gesture epitomises nearly two decades of relentless internationalisation of higher education, framed as an answer to the growing globalisation and the elevated goals of

\footnotetext{
${ }^{1}$ For the sake of the fluency of the text, we use the acronym only in some paragraphs.

${ }^{2}$ The other two being 'to put every child in school' and to 'improve the quality of learning' (http://www.unesco.org/new/en/gefi/).
} 
citizenship. This document appears at a time when many educational institutions around the globe are adopting global citizenship education as a foundation around which to organise their curricular activities (Andreotti, Biesta \& Ahenakew, 2015; Jorgenson \& Shultz, 2012; Shultz, Abdi \& Richardson, 2011; Yang, 2003).

This adoption, however, has not been without its problems. Whereas the official discourse (as presented in the UNESCO's strategy, for instance) anchors global citizenship education in the high values of social justice, solidarity, diversity and communitarian engagement, the implementation of this discourse into schools and higher education institutions seems to be thwarted by neoliberal practices, marked by a market rationality and the idea of an 'entrepreneurial citizen' (Burbules \& Torres, 2000; Camicia \& Franklin, 2011; Popkewitz, 2007). At stake here is the tension between two discourses, as recently identified by Camicia and Franklin (2011): one focused on individual achievements and self-investment (neoliberalism), and another one focusing on active, responsible citizenship (critical democracy). These two different discourses are not separated; rather, they appear side by side, causing a confusing effect: 'students are being prepared to participate as global citizens, but the meaning of this citizenship is complicated by a tension and blending between neoliberal and critical democratic discourses' (p. 321).

How is the blending being made and what are its outcomes? The research carried out by Camicia and Franklin (2011) suggests that nowadays the neoliberal discourse overpowers the critical democratic one, thus the necessity for the development of truly critical democratic practices in global citizenship education that could provide a countervailing force to the neoliberal discourses (p. 321). However, we will argue that the critical democratic discourse has instead an important ideological role in justifying the increasing commodification of higher education. Global citizenship education is precisely what makes it possible to harmonise these two apparently contradictory discourses into a narrative that disavows this contradiction. Not only the critical democratic discourse does not opposes the neoliberal structuring of higher education, this discourse can easily function as a fantasy that exculpates all of us who still want to work in universities, notwithstanding our dissatisfaction with their current commodification. What this narrative thus conceals is the crude impossibility of achieving the lofty values of critical democracy under the rule of today's capitalism.

In order to posit both discourses as necessary and complementary parts of the increasing commodification of education, we will rely on the contemporary theorisations on ideology by 
Slavoj Žižek. Whereas traditional ideology critique seeks to unravel the particular interests behind a given ideological statement, by analysing its inconsistencies in order to pierce the actual mode of its functioning (e.g. Marx \& Engels, 2000), it does so in an ineffective way since - and this is the main contribution of Žižek to ideology critique - it neglects the relation of ideology with what Lacan (2007) called jouissance or, in its anglicized form, enjoyment. What secures a given ideological edifice, what binds us to explicit ideologies, is not so much a rational decision, but a mode of enjoyment. Many academics have been criticizing the progressive marketization of education, making visible the impact of neoliberalism and globalisation on higher education, where bureaucrats, special interest groups and profitdriven corporate programs prevail over democratic tenets (e.g. Apple, 2006; Biesta, 2009; Brown, 2011). It has become a common place among academics to complain about the pressure to produce publications and score points in the academic ranking, as well as the constant pressures to find external funding and alliances with the private sector. Nonetheless, we all struggle to publish as much as we can and to play the funding game in a profitable manner. We do so in spite of better knowledge. The crucial question about ideology is thus not to be posited in terms of knowledge - what people need to know in order to break the ideological spell - but in terms of enjoyment: what do people enjoy that prevents them from changing? The attachment to something we know is 'wrong' can only be explained in terms of enjoyment: after the ideology has been exposed, we still do not change our behaviour because we enjoy it.

What do researchers enjoy that keeps them attached to the belief that global citizenship education can be a way to save education from neoliberal tenets? Global citizenship education is a favoured term for many funding agencies, and an energetic field of current educational research. Contrary to Camicia and Franklin's (2011, p. 321) observation that the discourse of critical democracy is becoming increasingly rare, a literature review as well as an analysis of the rhetoric used by national agencies, non-governmental institutions and universities to describe global citizenship education, shows that this discourse has instead become quite popular in the last two decades (e.g. Murray, 2006; Oxfam, 2003; Shultz, Abdi, \& Richardson, 2011). This makes global citizenship education a privileged area of research among educational sciences, with all the concomitant benefits of funding, working conditions and possibilities for research. Global citizenship education, although it might rest on the principles of critical democracy, is still going to be implemented in highly commoditised 
schools and universities, by people who are immersed in the dynamics of capitalist economics.

These contradictions in GCE have raised concerns for some researchers, who have been arguing for the need for studies to adopt a more critical and theoretical approach to the underlying assumptions of GCE (e.g. Andreotti, 2006; Mannion, Biesta, Priestley \& Ross, 2011; Marshall, 2011; Pashby, 2011). This article aims to contribute to our current understanding of educational policy, by analysing some of the relevant contemporary research on GCE. We begin by describing the neoliberal and critical democratic facets of GCE, and their entanglements. We then use elements of Žižek's philosophy to situate the content of these programmes, particularly the ones steaming from a critical democratic approach, against the background of global education. We argue that the discourse of GCE functions as an 'empty signifier' wherein antagonisms that pertain current education can be foreclosed and harmonised. Such a gesture allows us to have hope amidst an inherently exclusionary educational system; yet, it cancels any serious engagement with what are the concrete circumstances of today's schooling.

\section{Competing discourses}

The call for education to develop a more global orientation and to endow people with the knowledge, competences and attitudes that will prepare them for dealing with global issues is not new (e.g. Fujikane, 2003; Palmer, 1998; Parker, 2007). However, over the last decade, many of these diverse and dispersed projects have become crystallised under the overall umbrella of global citizenship education. Not only are educational institutions adopting global citizenship education as a main referent in their curricular and pedagogical activities, the amount of educational research dedicated to global citizenship education has also grown significantly in the last decade. We have today special issues of journals (e.g. Andreotti, 2011; Murray, 2006), anthologies (Banks, 2004; Noddings, 2004; O’Sullivan \& Pashby, 2008; Peters, Britton \& Blee, 2008; Shultz, Abdi \& Richardson, 2011; White \& Openshaw, 2005), and handbooks (e.g. Lewin, 2009), dedicated to the thematic of global citizenship education. ${ }^{3}$ These publications, by gathering the work of important scholars and encompassing different understandings and approaches to global citizenship education,

\footnotetext{
${ }^{3}$ Moreover, different subfields of educational research (such as Science Education, Mathematics Education, Teacher Education, etc.) have also been adopting global citizenship education has a main referent for thinking subject-matter educational issues (e.g. Skovsmose \& Valero, 2008; Vesterinen, Tolppanen \& Aksela, 2016).
} 
provide us with significant material to analyse the ideology pertaining to global citizenship education. In this article, we are interested in investigating the role played by two (often) opposite discourses that emerge when discussing the concept and the implications of global citizenship education.

The naming of these discourses may vary, but they all deal with the Marxian notion of class struggle, displayed in divisions such as communism and capitalism, left and right wing politics. These terms have been disappearing from the academic scene, where researchers prefer to use other terminologies such as critical democracy and neoliberalism (Camicia \& Franklin, 2011), ethically-driven and market-driven (Khoo, 2011), social justice and technical-economic agendas (Marshall, 2011), globalist and internationalist missions (Cambridge \& Thompson, 2004) ${ }^{4}$, critical and soft agendas (Andreotti, 2006), to refer to the binary at work in the way global citizenship education is perceived. No matter how they are named, these two discourses work as competing forces in the struggle to define the content and the practical implications of global citizenship education (Camicia \& Franklin, 2011; Andreotti, 2006). In what follows, we will briefly analyse what these discourses encompass and how they are present in today's research. We will use Camicia and Franklin's (2011) naming for the sake of categorisation.

\section{The neoliberal discourse}

Neoliberalism - or in Marxian terms, capitalism - concerns not only economy. Its functioning has taken over all areas of life through the 'economisation' of non-economic spheres and practices (Jameson, 1991; Brown, 2015; Žižek, 1989) - starting with the restructuring of the state through a business model (Brown, 2006) and the subsequent undoing of basic elements of democracy, ending with the transformation of its citizens (Brown, 2015). Brown (2015) adopts Foucault's idea of the 'homo oeconomicus' (Foucault, 2004, cited in Brown, 2015, p. 56), to describe today's citizens as spectres of human capital, who 'approach everything as a market and [know] only market conduct' (p. 39).

\footnotetext{
${ }^{4}$ There appears to be different understandings in research of what internationalisation and globalisation signify in terms of the political agendas they imply. For instance, while for Cambridge and Thompson (2004) internalisation is associated with a concern for greater human rights and global justice, and globalisation is more on the side of human capital theory and the neoliberal agenda; for Jorgenson and Shultz (2012), they signify the opposite, with internationalisation a name for the promotion of neo-liberal and corporatist views of education, linked to what is usually called 'knowledge society'.
} 
Underlying the neoliberal agenda is the idea that education should prepare people for an already given world. The purpose of education is not framed in terms of criticising, raising questions, imagining alternatives for today's political arrangements, but to optimise a system that is seen as the ultimate horizon for human sociability (e.g. Fukuyama, 1992). Problems are recognised, but perceived as malfunctions of an otherwise good system that needs to be improved. The aim is to educate people to become more competitive, entrepreneurial, individualistic (Brown, 2015). Questions about the world in which people are supposed to be active are not posed within a neoliberal educational frame. The problem is how to prepare people to fit in and succeed in this world (Jorgenson \& Schultz, 2012, p. 11). As a result, universities have become 'increasingly corporate in physical appearance, financial structure, evaluation metrics, management style, personnel, advertising and promotions' (Brown, 2011, p. 35). This is what Giroux (2010) called a 'business engaged in education', where students act as consumers, conceiving higher education as a 'personal investment (...) construed mainly in terms of earning capacity' (Brown, 2011, p. 23). Lurking in the background is the idea that education should have as its main purpose the raising of economic competitiveness (Sahlberg, 2006).

Scholars have been indicating the presence of this discourse in global citizenship education programmes (e.g. Biesta, 2009; Khoo, 2011). Khoo (2011) refers to the increasing influence of market-driven scenarios in education to signal how the logic of banking, profitability and national dominance in global markets has been eroding the existence of ethical scenarios that engage with alternative agendas based on human rights and ethical globalisation. Biesta (2011) has developed a critique on the way ideas such as 'active citizenship' approach the idea of a 'citizen' from the needs of the current sociopolitical order, by specifying the 'kinds of activities and "investments" that individuals need to make so that the specific sociopolitical order can be reproduced' (p. 38). These investments aim to foster cosmopolitan capital (Marshall, 2011), and to maintain the global status quo by promoting the globalisation of the capitalist economy and by serving the interests of global economic and cultural imperialism (Sleeter, 2003).

\section{The critical democratic discourse}

While the neoliberal discourse highlights the values of the market for the structuring of human relations, the discourse of critical democracy emphasises instead the principles of social justice, diversity, equality and deliberative democracy (as it is present in the works of 
Jürgen Habermas, for instance). As stressed by Camicia and Franklin (2011), critical democracy 'is based upon a deep commitment to multiculturalism, critical awareness of global power asymmetries, emancipation and social justice' (p. 314).

A significant part of the criticisms made to the neoliberal agenda in global citizenship education comes from a post-colonialist perspective (e.g. Andreotti, 2006, 2011; Parmenter, 2011). Authors have been criticising the western strategy that informs global citizenship education, arguing for 'decoloniality' and 'diversality' (Andreotti, 2011). Indeed, despite the positive and seemingly inclusiveness of the concept of global citizenship education, the fact remains that global citizenship education is indeed a very local and restricted concept. As exposed by Parmenter's (2011) study - an exhaustive mapping of the literature addressing global citizenship education from 1977 to 2009 - the geographic affiliation of the 263 authors of the articles showed how the transnational literature on global citizenship education is 'massively dominated by western, English speaking states' (p. 62). The United States of America, United Kingdom, Australia and Canada combined represent $85 \%$ of the institutional affiliations of the articles. Belgium, Hong Kong and Japan accounted for $6 \%$ of the articles. Countries like Cyprus, South Africa and India represented only each 1\% of the literature on global citizenship education. Jefferess (2008) argues that global citizenship comes attached to a privileged social background, making it an exclusive concept that separates the ones who are in the position of helping and the ones in need of help. The idea of helping and being responsible for the other turns the other into 'an object of benevolence' (Jefferess, 2008, p. 28). Moreover, global citizenship education is delivered by a 'white, liberal elite' (Heilman 2009, cited in Standish, 2014, p.182). It appears that the idea of global citizenship, although portraying a global community, is in reality privileging a very particular group of people.

A critical democratic reading of global citizenship education emphasizes the promotion of a sense of belonging to a larger community, through the encouragement of new ways of understanding and interacting with others, both at local and global levels (UNESCO, 2013, p. 4). The critical-democratic discourse in global citizenship defines a global citizen as someone who belongs to a global community, and whose responsibility is not limited to a specific area, but extended to a universal one (Jefferess, 2008). As such, global citizenship is seen as a way of transcending the boundaries created by each country, to enhance universal human rights (Dower, 2003, cited in Khoo, 2011), global interconnectedness (Torres, n.d, cited in UNESCO, 2014), and global ethical responsibility (Jefferess, 2008). 
Contrary to the unproblematic approach to the world conveyed by neoliberalism, critical democracy presupposes a critical engagement with the world. The current political, social, cultural and economic situation is seen as problematic, where new forms of colonialism emerge, economic and representative inequality arises, and environmental issues presses us to reformulate old practices. For critical democracy, the world is a mess, and global citizenship education is a way of turning the current situation into a more social just one. The way critical democratic perspectives conceive the level of transformation available is however problematic, and can easily be aligned with neoliberal tenets as we explore later in the article. As researchers have noticed (e.g. Hunter et al., 2006; Jorgenson \& Schultz, 2012; Marshall, 2011; Sleeter, 2003), while in policy and practice, global citizenship education has emerged to challenge the economic foci of education, the result seems to be a reproduction of the same system global citizenship education seeks to transform.

\section{Critical democracy as an antidote to neoliberalism}

These two discourses, although apparently opposing each other, often appear side by side in global citizenship education programmes, making them 'increasingly indistinguishable' (Marshall, 2011, p. 419). As an example of this blending, Camicia and Franklin (2011) analysed the 'Teach First' programme (Teach First, 2015), a project where successful graduates teach for two years in low income areas around England and Wales. The overall rhetoric of the programme is one of mitigating inequality by increasing access, achievement and aspirations of people from disadvantaged areas, thus pointing to the democratic orientation of this project. However, the entire structuring of the programme based on publicprivate partnerships indicates the presence of a neoliberal practice. It is as if teaching and its egalitarian purposes are not ends in themselves, but 'temporary ventures and practice fields for the more important realm of the market' (Camicia \& Franklin, 2011, p. 320). The authors conclude that the two discourses become somehow fused, to the detriment of the critical democratic discourse that is overpowered by the logic of neoliberalism present in the programme.

Different global citizenship scholars have noted the eroding of the critical democratic discourse in favour of the neoliberal one (e.g. Camicia \& Franklin, 2011; Khoo, 2011). As mentioned by Khoo (2011, p. 350),

current global conditions are highlighting the contradictions of internationalisation more starkly than ever, as financial pressures are pushing higher education institutions 
towards marketised, competitive and unethical interpretations of internationalisation, while ethical and cooperative development policies and programmes for mutual learning and benefit are eroded.

As a way to struggle against this neoliberal trend, researchers advocate a logic of compensation, wherein critical democratic and emancipatory discourses and practices compensate for the overriding influence of neoliberalism in education (Camicia \& Franklin, 2011; Huckle, 2004; Johnson, Boyer \& Brown, 2011; Jorgenson \& Shultz, 2012). As mentioned by Jorgenson and Shultz (2012, p. 1),

as global citizenship educators grapple with and respond to the global unevenness of internationalization, the legacies of colonialism, and ideologies that support a system that benefits the few at the expense of the many, educators look to global citizenship education efforts to open educational spaces for working for a more just and peaceful world.

Authors from a critical democratic vein advocate a stronger critical democratic discourse, so that this discourse can function as a counterforce to the now dominant neoliberal one (Blum \& Bourn, 2013; Thanosawan \& Laws, 2013). Although acknowledging the intertwined way in which these two discourses appear, researchers tend to posit both discourses as opposite, and invite us to choose the side of critical democracy. However, could it be that these two apparently contrasting agendas are not opposite but together form a 'composite' (Balarin, 2011 , p. 361), that strengthens (instead of alleviating) the neoliberal agenda?

\section{The place of enunciation}

At stake here is the gap between the enunciated content of a certain educational programme and its actualisation in a concrete setting, that is, its place of enunciation. Enunciated content and place of enunciation are Lacanian terms, which are used by Žižek to explore how the explicit rejection of an ideological hegemony can well involve the full endorsement of this same hegemony on the level of the position of enunciation (Žižek, 1997). The content of a statement can be analysed by focusing on the explicit message being conveyed by the subject. For instance, in the case of researchers who advocate critical democracy as a counter-force to the neoliberal educational agenda, the enunciated content of their statements can be hardly criticized in itself. Who would raise against the high goals of democracy, justice, diversity, sustainability and decoloniality? The problem arises when this same discourse is analysed not 
in itself, but as an act performed by a particular speaker or writer at a specific time and place. The place of enunciation is the place from where the subject speaks, the place where the high-goals of global citizenship education are going to be realised. Critical democratic approaches to global citizenship education do not exist in a political vacuum; rather they occur within a wider society that is 'reproducing powerful corporate cosmopolitan ideals entrenched in a set of neoliberal and knowledge-economy norms' (Marshall, 2011, p. 424). As noticed by Balarin (2011), global citizenship discourses rarely recognise that this presumed 'empirical reality' is entrenched within a system where social injustice is not an error to be corrected, but an essential requirement of the system. As Glass (2000) reminds us, 'wittingly or not, schools rank, sort, and merge masses into an ideological order that unfairly reproduces an unjust status quo' (p. 278).

The critical democratic discourse in global citizenship education seeks to uncover the processes that hide difference, create inequalities, and maintain exploitation. It is assumed that through pedagogical endeavours such as critical literacy and reflectivity, students can analyse their own positions in complex structures, with a view to changing them and their attendant assumptions, identities, attitudes and power relations (Andreotti, 2011). Some authors argue that global citizenship education is capable of instilling a collaborative work ethic among students (Taylor, 1996; Villegas \& Lucas, 2002), an understanding of citizenship that recasts autonomy and liberty (Hiskes, 1998), and orients our practices towards more humane and less antagonistic forms of educational policy and planning (Papastephanou, 2003). Such a display of students' engagement with education, however alluring in prospect, conceals a major question: what will make students work collaboratively and ethically towards a common goal amidst a school system that grades individually? The problem arises when we conceive education not as the realisation of a collectively motivated goal through continuous ethical commitment, but as the strictly individualistic goal of passing the course or achieving the highest grade. The school system is inherently individualistic, and this feature is obliterated in global citizenship education through the illusion that students are indeed working for a collective purpose. The antagonism that perpetrates schooling is disavowed by the fantasy of a collective of learners that does not match the real conditions of today's educational system.

A programme of global citizenship education designed by researchers is not the same as the concrete practice of global citizenship education in educational institutions. What makes 
them different are the different worlds they inhabit. A student is first and foremost a student, frequenting a specific place called school, with particular rules and organisation of labour. Research acumens such as critical literacy, reflexivity, collaborative ethical work, are going to be implemented in schools - the place of enunciation. The latter determines the true content of these proposals, so that, in the end, it becomes difficult to imagine how these suggestions can change any of the core features of the 'school's credit system' (Pais, 2012, p. 69). To believe that our enunciated intentions are going to be implemented in schools without some kind of 'misrecognition' is to neglect the crucial role that the place of enunciation - the entire political field structuring education - has in attributing meaning that was not intended by the subject. So the question to be posed is: What prevents global citizenship education, particularly within a critical democratic vein, from becoming commoditized, and thus utterly determined by the place of enunciation?

\section{Ideology: Taming the contradiction}

As we previously seen, authors that advocate a critical democratic approach see global citizenship education as an opportunity to counteract the pernicious influence of neoliberal policies and practices in today's education. Others, however, do not see any contradiction between the two discourses, and argue for a complementary relation between both (e.g. Held \& McGrew, 2003; Johnson, Boyer \& Brown, 2011; Jorgenson \& Shultz, 2012). According to Johnson, Boyer and Brown (2011), GCE is vital for the 'continued competitiveness of national economies and national security' (p. 516), and this endeavour complements the more humanistic goals of a critical approach to GCE:

In the end, then, those on the left can support this agenda for 'normative', humanistic reasons, while those more on the right can support a global studies agenda for security purposes. As a result, effective global education should be something that can be supported regardless of political orientation or nationality. (pp. 516-517)

Likewise, Held and McGrew (2003) argue that the interdependence of markets, technology, ideas and solidarity can enrich people's lives where there is an emphasis on shared values and a shared commitment to the development of all people. Here the combination of the two discourses appear side by side, seen as non-contradictory. 
Common to both discourses, is the idea that GCE is the path that contemporary education must follow if the purpose is to achieve a better world. Any contradictions that emerge from the confrontation of both discourses are disavowed, either by assuming that there is in fact no contradiction (as in the case of soft (Andreotti, 2016) approaches to GCE), or that the contradiction can be dealt with by focusing on identity change ${ }^{5}$ (as in critical approaches to GCE). The latter is particularly evident in the UNESCO (2013) discourse. Although there is an awareness of the tensions between different agendas for GCE, noticeable in the way the document raises questions such as "whether global citizenship education should promote global community outcomes or outcomes for individual learners' (p. 5); or 'how to promote, simultaneously, global solidarity and individual national competitiveness?' (p. 5); and 'how to bring together local and global identities and interests?' (p. 5); the document does not deal with any of these problematic questions. Instead, they are dismissed by the narrative that 'research and dialogue could facilitate the reconciliation of local and global identities and interests. Furthermore, in the perspective of diversity, the tensions can also be seen as a value' (p. 5). The solution for these tensions is conceived in terms of research and dialogue. That is, instead of being understood as the core contradictions undermining the ideal of a global world, these tensions are instead portrayed as empirical obstacles, possible to overcome through expert research and dialogue between conscious people.

At stake here is the way we conceptualise the contradictions that pertain to social reality. According to Mouffe (2005), opposite conflicting categories such as 'left' and 'right', 'individual' and 'collective', or 'solidarity' and 'competitiveness' have descended into a centralized acceptance of capitalism as the ontologized modus operandi of today's world. As stated by Mouffe (2005):

\footnotetext{
${ }^{5}$ Promotors of global citizenship education within a critical democratic vein often privilege the transformation of identities and take a normative approach to education (Balarin, 2011; Mannion, Biesta, Priestley \& Ross, 2011; Marshall, 2011; Pashby, 2011). Although recognising the political and economic dimension of the problem, the solutions proposed are often centred on changing 'mentalities'. Moreover, this discourse assumes that students and teachers are locally autonomous and well equipped with a faculty of choice (Jahng, 2013), which allows them to pursue their own critical global citizenship education programmes in spite of all constraints. This way, critical democratic discourses of global citizenship education, while embedded in a rhetoric of improving global power inequities, remain rooted in humanistic discourses that privilege individual change over structural transformation (Mannion, Biesta \& Priestley, 2011; Pashby, 2011). This erosion of the public sphere in favour of the private sphere, where people are expected to voluntarily 'do the right thing', is common to neoliberal and critical democratic approaches to global citizenship education.
} 
Nowadays politics operates supposedly on a neutral terrain and solutions are available that could satisfy everybody. Relations of power and their constitutive role in society are obliterated and the conflicts that they entail reduced to a simple competition of interests that can be harmonized through dialogue. (p. 111)

Indeed, this new all-encompassing category of people - the Citizen - stands precisely for this imaginary space of (neo)liberal-democracy where there is no antagonism: equal people discussing towards a common consensus. Against this view, Mouffe (2005) argues for the ruthless antagonistic constitution of the political field. This was the ground-breaking step taken by Ernesto Laclau and Chantal Mouffe in their book 'Hegemony and Socialist Strategy'. Against a liberal-corporative view of society based in the idea of consensus, they assert the constitutive status of social antagonism. According to them, the appeal for a consensus always implies a hegemonic act, by means of excluding the dissident voices, i.e., the ones who have to be excluded so that consensus could be reached (Laclau \& Mouffe, 1985). As explored by Mouffe (2005), in liberal-democracy the troubled 'other' is heard insofar as it is the voice tending to the consensus, the voice expected to be heard. According to her, the decisive achievement for democracy today is to recover the radical meaning of the Political - not as a utopian space of distributive justice (Rawls, 1999) or unpolluted communication (Habermas, 1984) - but a place of disagreement.

Slavoj Žižek has been further developing Laclau and Mouffe's insights on the political, through a revitalisation of the Marxian notion of ideology. Within the Lacan-Žižek axis ideology is conceived as a defence against a traumatic real, a 'fantasy-screen' (Žižek, 1997, p. 7) focused on restoring order to a situation that otherwise seems chaotic or impossible: a 'totality set in effacing the traces of its own impossibility' (p. 50). The discourse on global citizenship education can be conceived as an ideological formation set in order to dilute the contradictions inhering in the role of schools and universities. As explored by Mannion, Biesta and Priestley (2011), drawing on the work of Laclau and Mouffe (1985), global citizenship education functions as a 'nodal point' that attempts to 'fix meaning and bring together different discourses' (p. 444). Global citizenship education allows for the continuing commodification of higher education, but wrapped around a discourse of critical democracy and emancipation, so that the contradictions between community solidarity and individual competition, or between collective identity and individual identity are dismissed. This way, global citizenship education functions as a kind of 'empty container for the multitude of 
mutually exclusive meanings' (Žižek, 1997, p. 75). As an empty container, global citizenship education means that both critical, emancipatory education and market-oriented, reactionary education can work together in achieving the high goals of global citizenship education.

\section{Ideology: A defence against the real of our enjoyment}

Along these lines, not only are certain epistemological transitions currently unworkable, they provide the ideological material for critical researchers to continue following their radical educational agendas without posing any threat to the same system they criticise. Important here is the difference between the attitude that a certain educational proposal assumes towards the dominant relations of production, and the position of this same proposal within these relations of production. As posed by Žižek (1997), referring to the work of Walter Benjamin, 'a product whose explicit attitude is very critical towards the dominant relations of production often fits the frame of these relations perfectly' (p. 56). Going along with the ideology of global citizenship education brings enjoyment. It creates an entire educational and academic industry (from higher education programmes and funding schemes to conferences, journals, or international assessment mechanisms such as PISA) aimed at broadcasting the values of globalisation and citizenship across the world. This industry brings many of us a salary, partnerships, funding opportunities, academic excursions, and other means of enjoyment. However uncomfortably, all of us who work in the academia somehow take advantage of the branding of universities as global institutions. Students, on the other hand, might be well aware that workshops on 'how to write a Curriculum Vitae', 'network effectively' or 'be successful in interviews' (Manchester Metropolitan University, 2015) have little to do with the higher goals of global citizenship, but still they undertake the programme. Possessing these skills might give them little in terms of global citizenship, but will potentially place them ahead of other contesters for future jobs, which will allow them to achieve a better social status and ultimately a richer bank account - in other words, it allows them to enjoy all the little pleasures that populate a capitalist economy. In both cases, the real of capital is present, structuring people's actions, hindering us from acting according to what we know. It is important to remark that what we usually call ideology - the 'hidden' agenda that reduces global citizenship education to a mechanism of accountability, employability and credit - is not 'ideological' but real in the precise Lacanian sense: something that does not depend on my idea of it. 
Against this background, we can argue that the ideology of 'global citizenship education' is a defence against the real of our enjoyment: we need to know that the education for which we all strive is based on 'a sense of belonging to the global community and common humanity, with its presumed members experiencing solidarity and collective identity among themselves and collective responsibility at global level' (UNESCO, 2013, p. 3), so that we can accept the unequal, increasingly competitive reality in which we all work as educators. That is, the discourse on global citizenship education allows to perceive ourselves as ethical people, struggling for common goals through solidary efforts, while, at the same time, carrying on living our 'homo oeconomicus' lives. As argued by Žižek (1997), 'in contemporary consumerist societies, we, the subjects, are no longer interpelled on behalf of some ideological identity, but directly as subjects of pleasures, so that the implied ideological identity is invisible' (p. 11). What remains understated in the discourse around global citizenship education is the eminent subordination of education to the needs of the market. By buying into the critical-democratic discourse that encompasses global citizenship education, we can perceive ourselves as followers of a great cause, while the implied message delivered between the lines concerns the enjoyment with which we will be bribed if we subject ourselves to the cause. This is a case of what Žižek (1994) calls fetishist disavowal (Žižek, 1994): we know very well what is happening around the world, that globalisation actually means to impose the interests of a few to the lives of all, that democracy is in crisis, and that inequality pervades all societies; nevertheless, we continue to support the high goals of citizenship and globalisation. Standish (2014) argues that far from being altruistic, global citizenship is a self-serving practice, where citizenship means self-investment to increase self-value. Moreover, it assures that everybody has a place in the system: neoliberalists who are completely attuned with the depiction of schools and universities as businesses centred on knowledge (the so called 'knowledge economy'), and critical researchers who can build their careers criticising and imagining alternative possibilities.

\section{Conclusion}

Both soft and critical GCE programmes (Andreotti, 2006) pose education as a crucial dimension, either in producing the enterprising individuals who will be successful in the globalised world, or in producing the individuals that counteract this neoliberal tendency. While the ones that advocate a soft approach to GCE do not see a contradiction between GCE and current educational policies, the critical researchers, on the other hand, see GCE as an 
opportunity to counteract the current neoliberal hegemony that characterises education. GCE is then posited as the enterprise that will bring about a change towards more ethical, solidarity and democratic practices in education. Although recognising the constraints that the objective reality of schools and universities pose to the development of this programme, not much is said about the concrete circumstances that have to be met so that such an emancipatory programme can be successfully implemented. This is partly because critical approaches to GCE conceive individuals as the loci of change, as if students and teachers were disposed to work collectively. Both agendas thus perform a very important role within today's neoliberalism: they provide us with rationales for action, thus keeping us occupied, while at the same time inhibiting a structural analysis and a possibility of a change beyond individual agency.

Some will say that such an awareness of the problem is too pessimistic and only takes us to a deadlock. As mentioned by O'Connor and Zeichner (2011), 'without infusing the message of hope into the curriculum, teachers risk fuelling overwhelming feelings of cynicism, frustration and fear among students, leading them to feel "cognitively overwhelmed" and paralysed to take action (Hicks and Board, 2001)' (p. 532). Although acknowledging the endemic nature of exclusion in education, we need to believe that the goal for which we all strive is equality and freedom (that the presupposition of the system is a 'good' one), so that we can accept the unequal reality in which we live (Pais, 2013). We need to have 'hope', and infuse the message in anyone that crosses our path. Otherwise, we risk frustration and paralysis. The ethos of scientific research today makes plain that empty words are not enough; we must set to work, do it instead of just talking about it. What we need, some say, is engagement in action, quick solutions ready to be implemented, evaluated and, eventually, discarded, so that the entire process can start again. We argue that this pressure to produce 'solution-based' research is part of an ideological injunction to keep us occupied with specific research, while neglecting research that is not immediately concerned with providing solutions but rather to complicate the usual ways we approach problems. Some would say that such an approach to research will lead us into a state of paralysis, lost in an endless discussion from which no practical solutions, no 'insights for action' will emerge. Our response is that the true act sometimes could be a purely 'inactive' one. We strongly believe that sometimes the best way to act is to stop 'acting' - in the sense of doing research that immediately implies some kind of action - and ruminate. Žižek (2006) expresses this attitude as follows: 
The threat today is not passivity but pseudo-activity, the urge to "be active", to "participate", to mask the Nothingness of what goes on. People intervene all the time, "do something"; academics participate in meaningless "debates", and so forth, and the truly difficult thing is to step back, to withdraw from all this. Those in power often prefer even a "critical" participation, a dialogue, to silence - just to engage us in "dialogue", to make sure our ominous passivity is broken. (p. 334)

If the theorization we advanced leads to paralysis it will not be the worst of evils. It would be worse to keep the current state of affairs, wherein resources are disbursed in innocuous research, which has not been proved to have the solutions for the core educational problems of our time. Indeed, if teachers refuse to participate in school promotion, and if researchers reserve more time for contemplation instead of complying with market demands for fast research, perhaps paralysis would have a very disruptive effect. As put by Žižek above, the worst threat for the system today is not 'activism', but passivity: the refusal to comply with more of the same.

A final word begs to be said about our own position as researchers ${ }^{6}$, particularly concerning the enjoyment that we, as authors, are also gaining from writing and publishing this paper. After all, we also take advantage of the increasing importance given to GCE to develop this piece of research. Is there any difference between this research and the critical research in GCE that we criticise in this paper? Or, more tersely, is there any difference between our enjoyments? The answer is no. We, the authors, are as much part of the problem as everyone else working today in higher education. If there is a difference, it consists in the realisation that we are indeed part of the problem; and avoid taking refuge in the fantasy of a critical GCE. Our critique sought to show how GCE is brought to its end not when it finally succeeds - guaranteeing a meaningful global education for all - but when that which seems its fatal obstacle - neoliberalism - is experienced as its ultimate goal. Instead of running after the demand of making GCE more equitable, social just, democratic, and developing increasingly refined stratagems to better implement it in schools and higher education institutions, perhaps we should acknowledge the crude reality that education is not for all, that schools are places

\footnotetext{
${ }^{6} \mathrm{We}$ thank one of the anonymous reviewers for enticing us to write this final remark.
} 
of selection and teachers are agents of exclusion. These are the conditions of today's schooling, and research cannot afford dismissing them as being beyond its field of action.

\section{References}

Andreotti, V. (2006). Soft versus critical global citizenship education. Police \& Practice: A Development Education Review, 3, pp 40-51.

Andreotti, V. (2011). (Towards) decoloniality and diversality in global citizenship education. Globalisation, Societies and Education, 9(3-4), pp. 381-397.

Andreotti, V., Gert, B. \& Ahenakew, C. (2015). Between the nation and the globe: education for global mindedness in Finland. Globalisation, Societies and Education, 13(2), pp. 246-259.

Apple, M. (2006). Educating the "right" way: Markets, standards, God and Inequality. Oxon: Routledge.

Balarin, M. (2011). Global citizenship and marginalisation: contributions towards a political economy of global citizenship. Globalisation, Societies and Education, 9(3-4), pp. 355366.

Banks, J. (2004). Diversity and citizenship education: Global perspectives. San Francisco: John Wiley \& Sons.

Biesta, G. (2009). Education in the age of measurement: on the need to reconnect with the question of the purpose of education. Educational Assessment, Evaluation and Accountability, 21, pp. 33-46.

Biesta, G. (2011). Learning democracy in school and society: Education, lifelong learning, and the politics of citizenship. Rotterdam: Sense Publishers

Blum, N. \& Bourn, D. (2013). Global perspectives for global professionals in the UK: Engaging students within engineering and health. Compare, 33(1), pp. 37-55.

Brown, W. (2006). American nightmare: Neoliberalism, neoconservatism, and dedemocratisation. Political Theory, 34(6), pp. 690-714.

Brown, W. (2011). The end of educated democracy. Representations, 116(1), pp. 19-41.

Brown, W. (2015). Undoing the demos: Neoliberalism's stealth revolution. New York: Zone Books.

Burbules, N. \& Torres, C. (2000). Globalisation and education: Critical perspectives. New York: Routledge. 
Cambridge, J. \& Thompson, J. (2004). Internationalism and globalisation as contexts for international education. Compare: A Journal of Comparative and International Education. 32(2), pp. 161-175.

Camicia, S. \& Franklin, B. (2011). What type of global community and citizenship? Tangled discourses of neoliberalism and critical democracy in curriculum and its reform. Globalisation, Societies and Education. 9(3-4) pp. 311-322.

Fujikane, H. (2003). Approaches to global education in the United States, the United Kingdom and Japan. International Review of Education, 49(1-2), pp. 133-52.

Fukuyama, F. (1992). The end of history and the last man. New York: Free Press.

Giroux, H. (2010). Bare pedagogy and the scourge of neoliberalism: Rethinking higher education as a democratic public sphere. The Educational Forum, 74, pp. 184-196.

Glass, R.D. (2000). Education and the Ethics of Democratic Citizenship. Studies in philosophy and education, 19(3): pp. 275-296.

Habermas, J. (1984). A theory of communicative action vol. 1. Boston, MS: Beacon Press.

Haste, H. (2004). Constructing the citizen. Political Psychology, 25(3), pp. 413-439.

Held, D. \& McGrew, A. (2003). The global transformations reader. Cambridge: Polity Press.

Hiskes, R. (1998). Democracy, risk, and community: Technological hazards and the evolution of liberalism. New York: Oxford University Press.

Huckle, J. (2004). Citizenship education for sustainable development in initial teacher training. Available at http://www.citized.info/?r_menu induction\&strand 0 .

Hunter, W., White, G. P. \& Godbey, G. C. (2006). What does it mean to be globally competent? Journal of Studies in International Education, 10(3), pp. 267-285.

Ikeda, D (2005). Foreword. In N. Noddings (Ed.), Educating citizens for global awareness. New York: Teachers College Press.

Isin, E. \& Turner, B. (2002). Handbook of citizenship studies. London: Sage.

Jahng, K. (2013). Conceptualizing kindergarten education in South Korea: A postcolonial approach. Asia Pacific Journal of Education, 33(1), pp. 81-96.

Jameson, F. (1991). Post-modernism, or, the cultural logic of late capitalism. London: Verso. Jefferess, D. (2008). Global citizenship and the cultural politics of benevolence. Critical Literacy: Theories and Practices, 2(1) pp. 27-36.

Johnson, P., Boyer, M. \& Brown, S. (2011). Vital interests: Cultivating global competition in the international studies classroom. Globalisation, Societies and Education, 9(3-4), pp. 503-519. 
Jorgenson, S. \& Shultz, L. (2012). Global citizenship education (GCE) in post-secondary institutions: What is protected and what is hidden under the umbrella of GCE? Journal of Global Citizenship \& Equity Education, 2(1), no page.

Khoo, S. (2011). Ethical globalisation or privileged internationalisation? Exploring global citizenship and internationalisation in Irish and Canadian universities. Globalisation, Societies and Education, 9(3-4), pp. 337-353.

Lacan, J. (2007). The other side of psychoanalysis: The seminar of Jacques Lacan book XVII. New York: Norton \& Company.

Laclau, E. \& Mouffe, C. (1995). Hegemony and socialist strategy. London: Verso.

Lewin, R. (2009). The handbook of practice and research in study abroad: Higher education and the quest for global citizenship. New York: Routledge.

Manchester Metropolitan University (2015). Global Futures. Available at http://www.mmu.ac.uk/students/futures/global.php

Mannion, G., Biesta, G., Priestley, M. \& Ross, H. (2011). The global dimension in education and education for global citizenship: Genealogy and critique. Globalisation, Societies and Education. 9(3-4), pp. 443-456.

Marshall, H. (2011). Instrumentalism, ideals and imaginaries: Theorising the contested space of global citizenship education in schools. Globalisation, Societies and Education, 9(34), pp. 411-462.

Marx, K. \& Engels, F. (1932). A Critique of the German Ideology. Marx/Engels Internet Archive (www.marxists.org, accessed on $11^{\text {th }}$ of June 2016).

Mouffe, C. (2005). The democratic paradox. London: Verso.

Murray, S. (2006). Editorial. Policy \& Practice: A Development Education Review, 3, pp. 14.

Noddings, N. (2004). Educating citizens for global awareness. New York: Teachers College Press.

O’Connor, K. \& Zeichner, K. (2011). Preparing US teachers for critical global education. Globalisation, Societies and Education, 9(3-4), pp. 521-536.

O'Sullivan, M., \& Pashby, K. (2008). Citizenship education in the era of globalisation: Canadian perspectives. Rotterdam: Sense Publishers.

Oxfam (2003). Education for global citizenship. Oxfam Publishing, UK. 
Pais, A. (2012). A critical approach to equity in mathematics education. In O. Skovsmose \& B. Greer (Eds.), Opening the cage: Critique and politics of mathematics education. Rotterdam: Sense Publishers.

Pais, A. (2013). An ideology critique of the use-value of mathematics. Educational Studies in Mathematics, 84(1). 15-34.

Palmer, J.A. (1998). Environmental education in the 21st century: Theory, practice, progress, and Promise. London: Routledge.

Papastephanou, M. (2003). Forgiving and requesting forgiveness. Journal of Philosophy of Education, 37(3), pp. 503-524.

Parmenter, L. (2011). Power and place in the discourse of global citizenship education. Globalisation, Societies and Education, 9(3-4), pp. 367-380.

Parker, W.C. (2007). 'International education' in U.S. schools: The second wave. Washington State Kappan, 1, pp. 4-7.

Pashby, K. (2011). Cultivating global citizens: Planting new seeds or pruning the perennials? Looking for the citizen-subject in global citizenship education theory. Globalisation, Societies and Education, 9(3-4), pp. 427-442.

Peters, M., Britton, A. \& Blee, H. (2008). Global citizenship education: Philosophy, theory and practice. Rotterdam: Sense Publishers.

Popkewitz, T. (2007). Alchemies and governing: Or, questions about the questions we ask. Education, Philosophy and Theory, 39(1), pp. 64-83.

Rawls, J. (1999). A theory of justice. Oxford: Oxford University Press.

Shalberg, P. (2006). Education reform for raising economic competitiveness. Journal of Educational Change, 7(4), pp. 259-287.

Shultz, L., Abdi, A., \& Richardson, G. (2011). Global citizenship education in postsecondary institutions: Theories, practices, policies. New York: Peter Lang.

Skovsmose, O., \& Valero, P. (2008). Democratic access to powerful mathematical ideas. In L. D. English (Ed.), Handbook of international research in mathematics education. Directions for the 21st century (2nd ed., pp. 415-438). Mahwah, NJ: Erlbaum.

Sleeter, C. (2003). Teaching globalization. Multicultural Perspectives, 5(2), pp. 3-9.

Standish, A. (2014). What is global education and where is it taking us? The Curriculum Journal, 25(2) pp. 166-186.

Taylor, H. (1996). Practical suggestions for teaching global education, Eric Digests, pp. 1-7. Teach First (2015). Available at https://www.teachfirst.org.uk/. 
Thanosawan, P. \& Laws, K. (2013). Global citizenship: differing perspectives within two Thai higher education institutions. Journal of Higher Education Policy and Management, 35(3), pp. 293-304.

UNESCO (2013). Global citizenship education: An emerging perspective. Available at http://unesdoc.unesco.org/images/0022/002241/224115E.pdf.

UNESCO (2014). Global citizenship education: preparing learners for the challenges of the $21^{\text {st }}$ century. Paris: UNESCO.

Vesterinen, V., Tolppanen, S., Aksela, M. (2016). Toward citizenship science education: What students do to make the world a better place? International Journal of Science Education, 38(1), pp. 30-50.

Veugelers, W. (2007). Creating critical-democratic citizenship education: Empowering humanity and democracy in Dutch education. Compare, 37(1), pp. 105-119.

Villegas, A. \& Lucas, T. (2002). Preparing culturally responsive teachers: Rethinking the curriculum. Journal of Teacher Education, 53(1), pp. 20-32.

White, C. \& Openshaw, R. (2005). Democracy and the crossroads: International perspectives on critical global citizenship education. Oxford: Lexington Books.

Yang, R. (2003). Globalisation and higher education development: A critical analysis. International Review of Education, 49(3-4), pp. 269-291.

Žižek, S. (1989). The sublime object of ideology. London: Verso.

Žižek, S. (1994). How did Marx invent the symptom? In Žižek, S. (Ed.), Mapping ideology. London: Verso.

Žižek, S. (1997). The plague of fantasies. London: Verso.

Žižek, S. (2006). The parallax view. Cambridge, MA: MIT Press. 